\title{
Hunger States Control the Directions of Synaptic Plasticity via Switching Cell Type-Specific Subunits of NMDA Receptors
}

\author{
Yong $\mathbf{Q i}^{1,2}$ and ${ }^{\circ}$ Yunlei Yang ${ }^{1}$ \\ 'Department of Neuroscience and Physiology, State University of New York Upstate Medical University, Syracuse, New York 13210, and 2Zhengzhou \\ University People’s Hospital (He’nan Provincial People’s Hospital), Zhengzhou 450003, China
}

It remains largely unknown whether and how hunger states control activity-dependent synaptic plasticity, such as long-term potentiation (LTP) and long-term depression (LTD). We here report that both LTP and LTD of excitatory synaptic strength within the appetite control circuits residing in hypothalamic arcuate nucleus (ARC) behave in a manner of hunger states dependence and cell type specificity. For instance, we find that tetanic stimulation induces LTP at orexigenic agouti-related protein (AgRP) neurons in ad libitum fed mice, whereas it induces LTD in food-deprived mice. In an opposite direction, the same induction protocol induces LTD at anorexigenic pro-opiomelanocortin (POMC) neurons in fed mice but weak LTP in deprived mice. Mechanistically, we also find that food deprivation increases the expressions of NR2C/NR2D/NR3-containing NMDA receptors (NMDARs) at AgRP neurons that contribute to the inductions of LTD, whereas it decreases their expressions at POMC neurons. Collectively, our data reveal that hunger states control the directions of activity-dependent synaptic plasticity by switching NMDA receptor subpopulations in a cell type-specific manner, providing insights into NMDAR-mediated interactions between energy states and associative memory.

Key words: AgRP neuron; food deprivation; LTD; LTP; NMDA receptor; POMC neuron

Significance Statement

Based on the experiments performed in this study, we demonstrate that activity-dependent synaptic plasticity is also under the control of energy states by regulating NMDAR subpopulations in a cell type-specific manner. We thus propose a reversible memory configuration constructed from energy states-dependent cell type-specific bidirectional conversions of LTP and LTD. Together with the distinct functional roles played by NMDAR signaling in the control of food intake and energy states, these findings reveal a new reciprocal interaction between energy states and associative memory, one that might serve as a target for therapeutic treatments of the energy-related memory disorders or vice versa.

\section{Introduction}

Synapses have a potential memory capacity through the alterations of synaptic strength, such as activity-dependent synaptic plasticity (Gordon and Bains, 2006). For instance, long-term potentiation (LTP) and long-term depression (LTD) are two types of synaptic plasticity, persistent opposite modifications of synaptic strength

\footnotetext{
Received March 4, 2015; revised July 31, 2015; accepted Aug. 23, 2015.

Author contributions: Y.Y. and Y.Q. designed research; Y.Y. and Y.Q. performed research; Y.Y. analyzed data; Y.Y. and Y.Q. wrote the paper.

This work was supported by the State University of New York. We thank all the members of the Y.Y. laboratory for critical comments on the early version of this manuscript; Robert Quinn for mouse husbandry; Arvydas Matiukas for the help with imaging; and Karen Gentile for the help with single-cell RT-PCR.

The authors declare no competing financial interests.

Correspondence should be addressed to Dr. Yunlei Yang, Department of Neuroscience and Physiology, State University of New York Upstate Medical University, Syracuse, NY 13210. E-mail: yangyun@upstate.edu.

DOI:10.1523/JNEUROSCI.0855-15.2015

Copyright $\odot 2015$ the authors $\quad 0270-6474 / 15 / 3513171-12 \$ 15.00 / 0$
}

(Martin et al., 2000). One of the mechanisms underlying the bidirectional synaptic alterations is the specific afferent stimulation that produces LTP or LTD by activating different NMDA receptor subunits (Hrabetova et al., 2000). NMDA receptors consist of glycinebinding $\mathrm{NR}_{1}$, glutamate-binding $\mathrm{NR}_{2}$, and the most recently discovered glycine-binding $\mathrm{NR}_{3}$ subunits (Dingledine et al., 1999). Activation of distinct subpopulations of NMDA receptors determines the directions of the alterations of synaptic strength, such as LTP and LTD. For instance, NR2A/NR2B-containing NMDA receptors contribute to LTP induction, whereas NR2C/NR2Dcontaining NMDARs contribute to LTD induction (Hrabetova et al., 2000). Meanwhile, emerging evidence indicates that D-serine, well known to enhance NMDAR-mediated currents by binding to NR1 subunits (Wolosker et al., 1999; Stevens et al., 2003; Yang et al., 2003; Mothet et al., 2005), exerted inhibitory effects on NR3containing receptors-mediated currents (Chatterton et al., 2002; 
Awobuluyi et al., 2007). It was also reported that NR3-containng NMDA receptors exerted negative regulations on the formation of dendritic spines (Das et al., 1998) and synaptic functions (Ciabarra et al., 1995; Sucher et al., 1995; Roberts et al., 2009). Moreover, the NR3-containing receptors decreased the functions of NMDA receptors by reducing $\mathrm{Ca}^{2+}$ permeability (Das et al., 1998; Nishi et al., 2001; Matsuda et al., 2003). Together, these results suggest that NMDA receptors play distinct roles in regulating synaptic functions and plasticity with different NMDA receptor subpopulations under different conditions, such as energy surfeit and deficit, respectively.

Agouti-related protein (AgRP) and pro-opiomelanocortin (POMC) neurons are two molecularly defined populations residing in the hypothalamic arcuate nucleus (ARC), a key brain region that control energy intake and expenditure. An extensive literature demonstrates that AgRP and POMC neurons play distinct functions in the control of food intake (Aponte et al., 2011; Atasoy et al., 2012; Schneeberger et al., 2013), although these two populations are intermingled in the ARC (Yang et al., 2011). For instance, food intake was promoted by increasing the firing rate of AgRP neurons but reduced by activating POMC neurons (Aponte et al., 2011). Interestingly, recent studies reported that food deprivation enhanced excitatory synapse transmissions at and firing rate of orexigenic AgRP neurons, whereas it decreased them at anorexigenic POMC neurons (Yang et al., 2011; Liu et al., 2012). These results demonstrate a reciprocal interaction between energy states and synaptic functions of the appetite control circuits.

However, an important but little explored area is whether and how energy states control activity-dependent synaptic plasticity that may serve as a cellular mechanism underlying learning and memory (Bliss and Collingridge, 1993; Martin et al., 2000). To study this, we performed whole-cell patch-clamp recordings at $\mathrm{AgRP}$ and POMC neurons in the acute brain slices that contain hypothalamic ARC and ventromedial hypothalamus (VMH) in NPY-hrGFP and POMC-EGFP transgenic mice, respectively. Tetanic stimulation of the presynaptic afferents onto AgRP and POMC, respectively, was applied to induce long-term synaptic plasticity. We find that LTP is induced at AgRP neurons in ad libitum fed mice, whereas the same induction protocol induces LTD in food-deprived mice; by contrast, the tetanic stimulation induces LTD at POMC neurons in ad libitum fed mice, whereas it induces weak LTP in the deprived mice. Mechanistically, we also find that food deprivation switches the expressions of NMDAR subpopulations in a cell type-specific manner. Based on these results, we propose a memory device for physiological state constructed from experience-dependent cell type-specific synaptic plasticity, one that is flipped between synaptic potentiation and depression of the appetite control circuits under the conditions of energy surfeit and deficit, respectively.

\section{Materials and Methods}

Experimental protocols were conducted according to National Institutes of Health guidelines for animal research and were approved by the Institutional Animal Care and Use Committee at State University of New York Upstate Medical University. Food deprivation was for $24 \mathrm{~h}$, starting at 09:00 without food supply but with free access to water.

For the experiments performed in Figure 5 and Figure $9 A, B$, the experimenter was blinded to the identity of the deprivation state of the animal.

Animals. All NPY-hrGFP and POMC-EGFP transgenic mice were purchased from The Jackson Laboratory. The transgenic mice were genotyped for $G f p$. Only male mice (age 6-8 weeks) were used. Every five mice were housed in one cage on a $12 \mathrm{~h}$ light (07:00)/dark (19:00) cycle with ad libitum access to water and mouse chow (PicoLab Rodent Diet 20, 5053 tablet, TestDiet) unless otherwise noted. The mice were singlecaged at least 1 week before performing the experiments.
Pharmacology. All chemicals were purchased from Sigma, except as follows. PPDA [(2S*,3R*)-1-(phenanthren-2-carbonyl) piperazine-2, 3 -dicarboxylic acid] and threo ifenprodil hemitartrate [(1S*,2S*)-threo2-(4-benzylpiperidino)-1-(4-hydroxyphenyl)-1-propanol hemitartrate] were purchased from Tocris Bioscience. Chemicals were applied to brain slices through the bath by addition to the circulating perfusion solution.

Slice preparation. All the experiments were performed in the early light period with brain slices prepared at 09:00. Acute brain slices that include hypothalamic ARC and VMH were prepared as described in our previous work (Yang et al., 2011, 2015). Briefly, mice were deeply anesthetized with isoflurane and decapitated. The mouse brains were dissected rapidly and placed in ice-cold oxygenated $\left(95 \% \mathrm{O}_{2}\right.$ and $\left.5 \% \mathrm{CO}_{2}\right)$ solution containing the following (in $\mathrm{mm}$ ): 110 choline chloride, $2.5 \mathrm{KCl}, 1.25 \mathrm{~mm}$ $\mathrm{NaH}_{2} \mathrm{PO}_{4}, 2 \mathrm{CaCl}_{2}, 7 \mathrm{MgSO}_{4}, 25$ D-glucose, $3.1 \mathrm{Na}$-pyruvate, and 11.6 $\mathrm{Na}$-L-ascorbate, $\mathrm{pH}$ 7.3. Coronal brain slices ( $260 \mu \mathrm{m}$ thick) were cute with a vibratome (Leica VT 1000S) and maintained in an incubation chamber for $34^{\circ} \mathrm{C}$ for $30 \mathrm{~min}$, and then brought to room temperature until transferred to a recording chamber. During experiments, an individual slice was transferred to a submersion-recording chamber and was continuously perfused with the recording solution containing the following (in mM): $119 \mathrm{NaCl}, 25 \mathrm{NaHCO}_{3}, 11 \mathrm{D}$-glucose, $2.5 \mathrm{KCl}, 1.25 \mathrm{MgCl}_{2}, 2$ $\mathrm{CaCl}_{2}$, and $1.25 \mathrm{NaH}_{2} \mathrm{PO}_{4}$, aerated with $95 \% \mathrm{O}_{2} / 5 \% \mathrm{CO}_{2}(1-2 \mathrm{ml} / \mathrm{min}$ at $26^{\circ} \mathrm{C}-28^{\circ} \mathrm{C}$ ), except where noted. Typically, three brain slices containing both $\mathrm{VMH}$ and the ARC were obtained for each animal. GFP-labeled AgRP and POMC neurons were identified using a Nikon microscope by fluorescence emission and then visually targeted with infrared gradient contrast optics.

Electrophysiology. All experiments were performed in the presence of $\mathrm{GABA}_{\mathrm{A}}$ receptor antagonist picrotoxin $(50 \mu \mathrm{M})$. Neurons were patched using electrodes with tip resistances at 2.0-3.0 $\mathrm{M} \Omega$. Recording pipettes were routinely filled with a solution containing the following (in $\mathrm{mM}$ ): $125 \mathrm{~K}$-gluconate, $15 \mathrm{KCl}, 10 \mathrm{HEPES}, 8 \mathrm{NaCl}, 4 \mathrm{Mg}$-ATP, $0.3 \mathrm{Na}$-GTP, 10 $\mathrm{Na}_{2}$-phosphocreatine, 2 EGTA, pH 7.30, except where noted. Whole-cell patch-clamp recordings were made at AgRP and POMC neurons in the ARC. The holding potential for voltage-clamp recordings was $-60 \mathrm{mV}$, and responses were digitized at $10 \mathrm{kHz}$. Neurons with series resistances $<30 \mathrm{M} \Omega$ and access resistances $>1 \mathrm{G} \Omega$ were used for recordings. As described previously (Yang et al., 2011), EPSCs were evoked with an isolated Pulse Stimulator (WPI) using a concentric bipolar electrode (FHC, CBAEC75) placed at ventrolateral, middle, or ventromedial segment of the border between ARC and VMH. EPSCs with amplitudes in the range of $50-100 \mathrm{pA}$ were elicited by $0.1 \mathrm{~ms}$ electrical stimuli (100$300 \mu \mathrm{A}$ ) every $20 \mathrm{~s}$. Activity-dependent synaptic plasticity was induced using one train of tetanic stimuli consisting of 100 pulses at $100 \mathrm{~Hz}$ or at $50 \mathrm{~Hz}$ while the neurons were held at $-60 \mathrm{mV}$. Data were accepted for analysis only when postsynaptic currents did not vary beyond $15 \%$ of the averaged values during the control period, and the input resistance remained constant throughout the whole experiment.

In the experiments when the ratios of NMDAR/AMPAR were calculated, EPSCs with both NMDAR and AMPAR components were recorded in $\mathrm{Mg}^{2+}$-free extracellular medium while the neurons were held at $-60 \mathrm{mV}$. To calculate the NMDARs-mediated synaptic currents (NMDAR-EPSCs), the evoked total EPSCs (average of 15-30 trials) at baseline subtracted from the AMPAR-mediated EPSCs (AMPAR-EPSCs; average of 15-30 trials) recorded during the stable state starting at $5 \mathrm{~min}$ after blockade of NMDARs by APV $(50 \mu \mathrm{M})$. As an independent measurement, NMDAR and AMPAR components of EPSCs were also calculated temporally based on their distinct kinetics (Hestrin et al., 1990; Watt et al., 2000; Yang et al., 2003). For instance, the amplitudes of NMDAR-EPSCs were calculated in a time window between 10 and $20 \mathrm{~ms}$ after the peak of AMPAR-mediated currents, which has a fast rising time $<1 \mathrm{~ms}$. The EPSCs were recorded using MultiClamp 700B amplifier and analyzed with pClamp 10.0 (Molecular Devices). In most cases, recordings were initiated $5 \mathrm{~min}$ after the whole-cell configurations were established.

Immunofluorescence assays and imaging. The ad libitum fed and fooddeprived NPY-hrGFP and POMC-EGFP mice were perfused by using $4 \%$ PFA in PBS, and the mouse brains were sectioned. Briefly, the mice were deeply anesthetized with ketamine and then perfused transcardially with 
$\mathbf{A}_{1}$

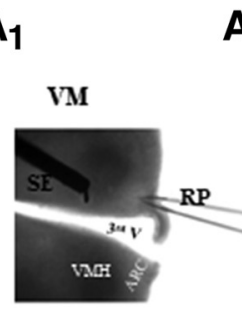

$\mathrm{A}_{2}$

$\mathbf{A}_{3}$

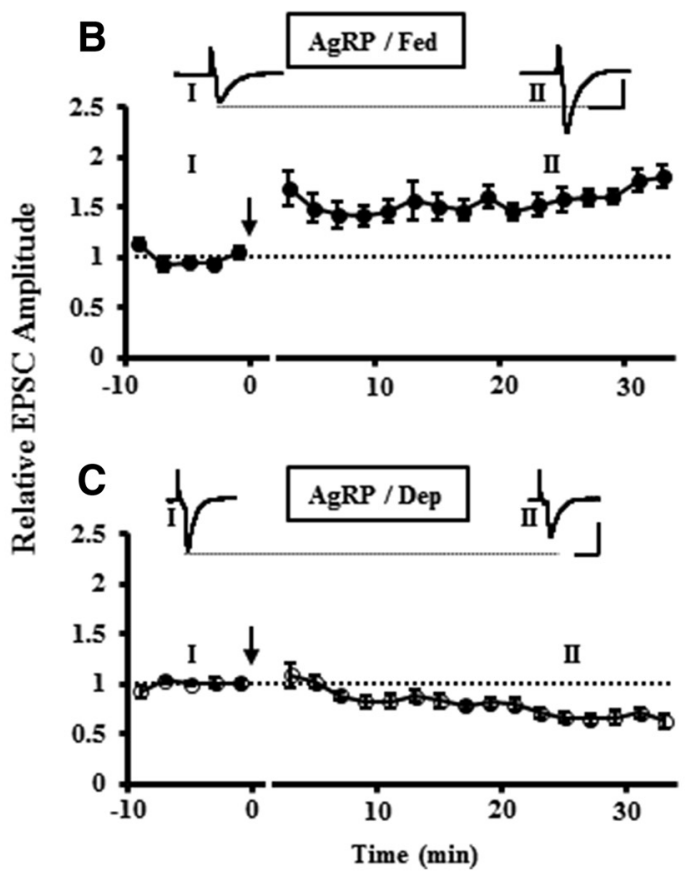

VL
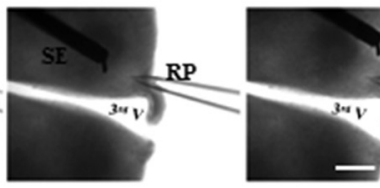

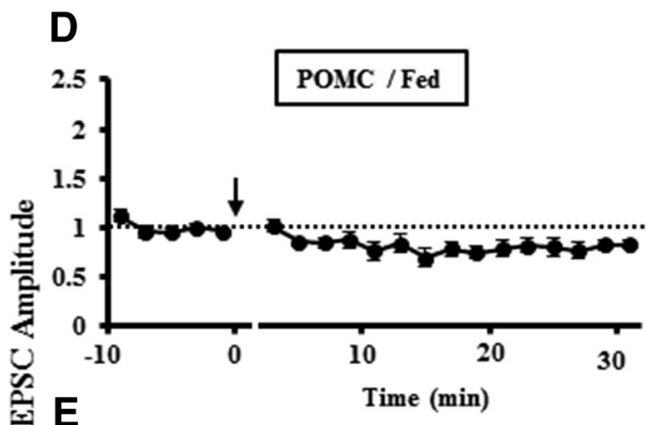

田
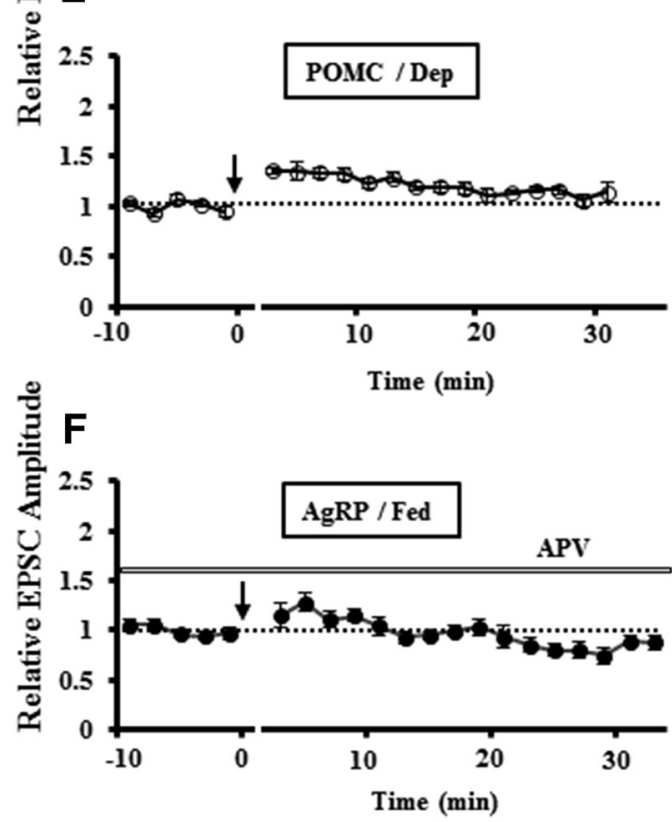

Figure 1. Comparing synaptic plasticity induced by tetanic stimulation at AgRP and POMC neurons in fed and food-deprived mice. $A_{1}-A_{3}$, Phase-contrast images showing the positions of stimulating electrodes (SE) and recording pipette (RP) placed in the acute brain slices that include VMH and hypothalamic ARC. $A_{1}$, Ventromedial (VM). $A_{2}$, Middle (M). $A_{3}$, Ventrolateral (VL). 3 rd V, Third ventricle. $\boldsymbol{B}$, Tetanic stimulation induced LTP at AgRP neurons in ad libitum fed mice ( $n=10$ slices $/ 5$ mice). $\boldsymbol{C}$, Tetanic stimulation induced LTD at AgRP neurons in food-deprived mice ( $n=$ 15 slices $/ 7$ mice). D, LTD was induced by tetanic stimulation at POMC neurons in ad libitum fed mice ( $n=6$ slices $/ 3$ mice). $\boldsymbol{E}$, Weak LTP was induced at POMC neurons in food-deprived mice $(n=$ 8 slices/4 mice). $\boldsymbol{F}$, Dependence of LTP induction at AgRP neurons in fed mice. LTP induction at AgRP neurons in fed mice was blocked in the presence of NMDAR antagonist APV ( $50 \mu \mathrm{M})(n=7 \mathrm{slices} / 3$ mice). Data represent averages from all the experiments. The amplitude of EPSCs was normalized by the mean amplitude observed during the control period (I) ( $t=-10$ to 0 min). The percentage changes of the amplitude of averaged EPSCs recorded at 20-30 min after induction are as below: for AgRP neurons (B, Fed: $1.49 \pm 0.07 ; \boldsymbol{C}$, Dep: $0.71 \pm 0.04 ; \boldsymbol{F}$, Fed/APV: $0.84 \pm 0.06 ; p<0.001$, compared with Fed group), and for POMC neurons ( $\boldsymbol{D}$, Fed: $0.80 \pm 0.07 ; \boldsymbol{E}$, Dep: $1.07 \pm 0.06 ; p<0.01$ ). Arrows indicate the time of tetanic stimulation. Traces represent samples of averaged EPSCs from one experiment during the control period (I) and at $20-30$ min after tetanic stimulation (II) (30 trials for each). Scale bars: photo images, $500 \mu \mathrm{m}$. Calibration: recording traces, $100 \mathrm{pA}, 10 \mathrm{~ms}$. Dep, Food deprivation.

PBS, $\mathrm{pH} 7.4$, followed by $4 \%$ PFA in PBS. Brains were removed and placed in $4 \%$ PFA overnight. Hypothalamic coronal brain sections (40 $\mu \mathrm{m}$ ), including medial basal hypothalamus, were sectioned by using Cryostat (Leica) or vibratome (Leica VT 1000S) for immunostaining and subsequent imaging.

For NR3A and NR3B subunit immunofluorescence assays, the brain sections that contain the ARC were stained using rabbit anti-NR3A or NR3B antibodies. Briefly, the brain sections were washed three times in PBS for 10 min each time and subsequently switched to the blocking solution in PBS containing 1\% BSA for $1 \mathrm{~h}$. The brain sections were then incubated overnight at $4^{\circ} \mathrm{C}$ with the primary antibody rabbit anti-NR3Aconjugated fluorophore Alexa-555 (1:300 and overnight, Bioss) or rabbit anti-NR3B-conjugated fluorophore Alexa-647 (1:300 and overnight, Bioss), respectively, which were diluted in PBS supplemented with $1 \%$ BSA. The brain sections were then rinsed three times in PBS and mounted on glass slides using mounting medium (Southern Biotechnology), and coverslipped for imaging. Of note, in all the aforementioned solutions, Triton X-100 was not added in order not to break the cell membrane because we focused on staining the membrane surface NR3A and NR3B subunits at AgRP and POMC neurons, respectively.
Image analysis was performed blind with the person analyzing the images having no knowledge of the identity of the samples during the analysis. Confocal images ( $4 \mu \mathrm{m}$ thickness, $8-10$ images) were taken using $40 \times$ objective at a resolution of $512 \times 512$ or $1024 \times 1024$ pixels per frame, and an average of two was used. The GFP-positive neurons were counted in a single section at the center of the stack to collect most of the GFP-positive neurons in each brain section. For each mouse, GFPpositive neurons were counted from two or three brain sections at the center of the ARC. To measure fluorescence signal intensity of the surface NR3A and NR3B at AgRP and POMC neurons in fed and food-deprived mice, respectively, an automated image analysis software based on ImageJ was used to quantify changes in the signal intensity of surface NR3A and NR3B at AgRP and POMC neurons. Briefly, the images were first thresholded to eliminate background fluorescence, and the integrated fluorescence intensity on each GFP-labeled neuron was automatically measured. According to the soma size of AgRP and POMC neurons, we set the size of the analyzer particles as $50 \mu \mathrm{m}^{2}$ in our experimental conditions so that the majority of the GFP-labeled neurons were counted with precluding the small segment of GFP-labeled dendrite or the cut neuronal soma. Using the described criteria, the GFP-labeled neurons 
A
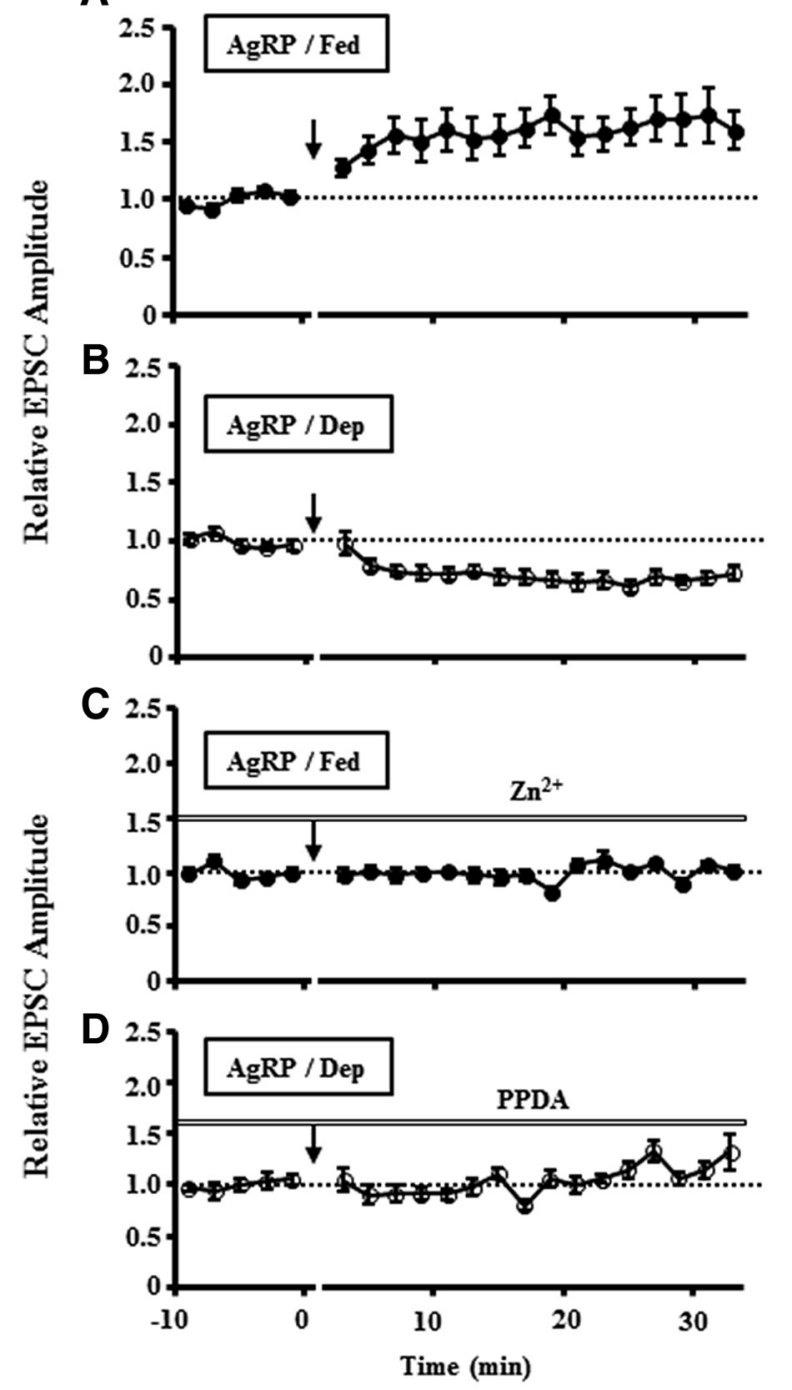

E
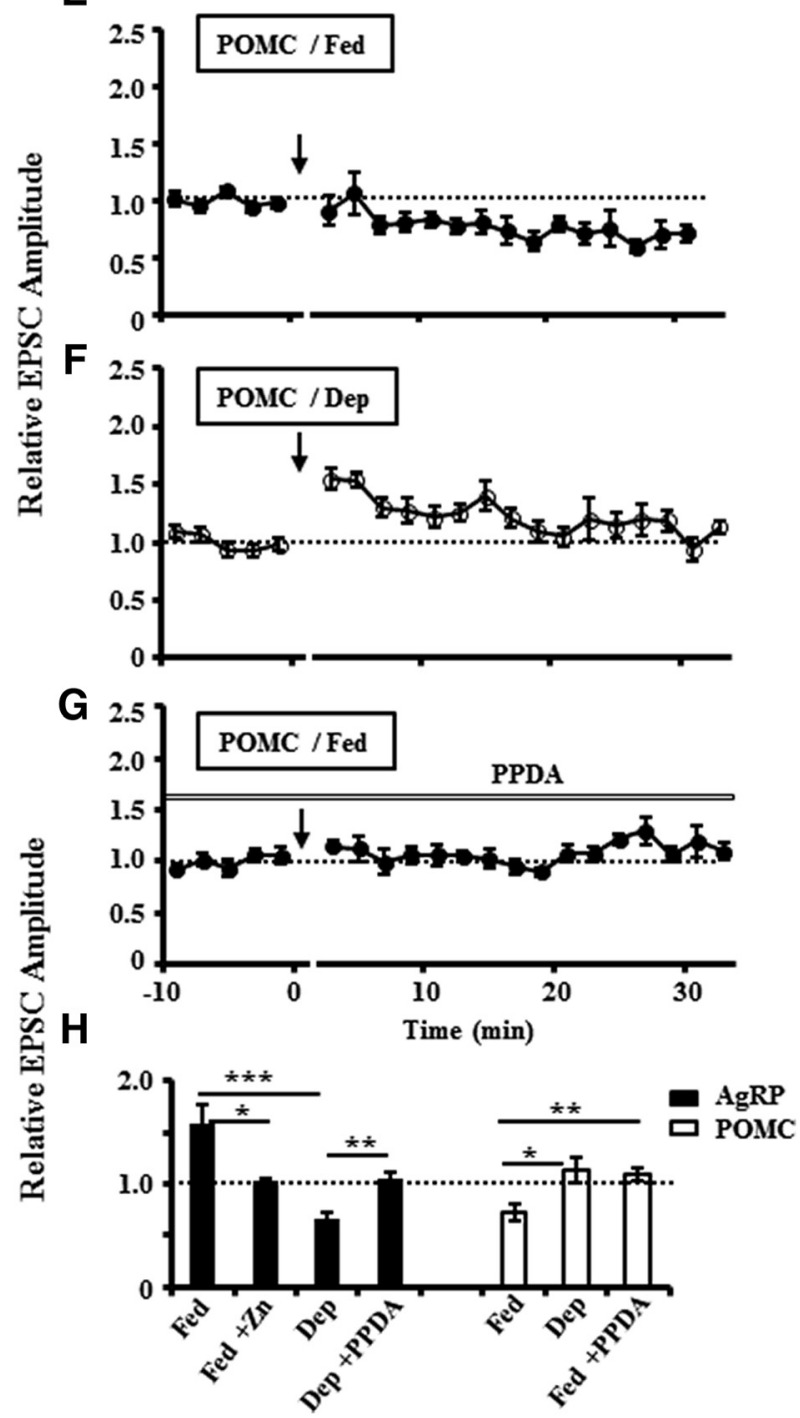

Figure 2. Dependence of LTP and LTD inductions at AgRP and POMC neurons in fed and deprived mice on NMDAR subpopulations. Identical to the data shown in the Figure 1, the inductions of LTP $(\boldsymbol{A})$ and LTD $(\boldsymbol{B})$ were repeated at AgRP neurons in fed and deprived mice, respectively, with presynaptic afferent stimulation of 100 pulses at $50 \mathrm{~Hz}$ in $5 \mathrm{~mm}$ glucose. $\boldsymbol{C}$, LTP induction in fed mice was diminished in the presence of NR2A-selective blocker $\mathrm{Zn}^{2+}$. D, LTD induction in food-deprived mice was abolished in the presence of NR2C/NR2D-selective blocker PPDA. E, $F$, In the same conditions as mentioned above, the inductions of LTD $(\boldsymbol{E})$ and weak LTP $(\boldsymbol{F})$ were repeated at POMC neurons in fed and deprived mice, respectively. $\boldsymbol{G}$, Treatments of the brain slices with PPDA diminished the induction of LTD at POMC neurons in fed mice. $\boldsymbol{H}$, Summary of results from all experiments in $\boldsymbol{A}-\boldsymbol{G}$. The relative EPSC amplitude was measured by the mean amplitude of EPSCs at $20-30 \mathrm{~min}$ after induction, normalized in each neuron by the mean EPSC amplitude observed during the control period ( -10 to $0 \mathrm{~min})(\mathrm{AgRP} / \mathrm{Fed}: 1.59 \pm 0.18, n=14 \mathrm{slices} / 6 \mathrm{mice} ; \mathrm{AgRP} / \mathrm{Fed} / \mathrm{Zn}$ : $1.03 \pm 0.02, n=7$ slices/3 mice; AgRP/Dep:0.66 $\pm 0.06, n=8$ slices/4 mice; AgRP/Dep/PPDA, $1.04 \pm 0.08, n=7$ slices/3 mice;POMC/Fed: $0.72 \pm 0.08, n=9$ slices/4 mice; POMC/Dep: $1.13 \pm$ $0.12, n=8$ slices/3 mice; POMC/Fed/PPDA: $1.09 \pm 0.05, n=6$ slices/3 mice). Dep, Food deprivation. ${ }^{*} p<0.05,{ }^{* *} p<0.01,{ }^{* * *} p<0.001$ (Student's unpaired $t$ test).

were automatically selected and analyzed for the signal intensity of NR3A and NR3B. We normalized the surface intensity of NR3A and NR3B at the soma of AgRP and POMC neurons in deprived mice, respectively, to that obtained in fed mice for each group. Images were acquired and analyzed using LSM (Zeiss Confocal 710) and ImageJ software.

Single-cell gene expression profiling and analysis. As described in Electrophysiology, acute brain slices that contain ARC were prepared from fed and food-deprived mice. We followed the procedures as detailed in the documents of Single Cell-to- $\mathrm{C}_{\mathrm{t}}$ Kit (Invitrogen) and the previous report (Jennings et al., 2013) with minor revisions. Briefly, the patch electrodes $(2.0-3.0 \mathrm{~m} \Omega)$ were autoclaved to remove any possible contaminants and then backfilled with an internal solution containing the following (in mM): $125 \mathrm{~K}$-glutamate, 2 EGTA, $10 \mathrm{HEPES}, 1.5 \mathrm{MgSO}_{4}$ in RNase- and DNase-free water. A total of $5 \mu \mathrm{l}$ of RNase inhibitor was added per $1 \mathrm{ml}$ of the internal solution. Whole-cell patch-clamp configurations were made at the neurons using the same criteria as described in Electrophysiology. The cytoplasm of the recorded neuron was slightly aspirated by applying negative pressure for $\sim 5-10 \mathrm{~s}$, and the whole-cell configuration was monitored during aspiration to prevent extracellular contamination. Immediately after finishing aspiration and waiting $\sim 10 \mathrm{~s}$ in order not to aspire extracellular solution by releasing the remaining negative pressure in the recording pipette, the pipette tip was pulled from the recorded neuron and broken into an RNase-free PCR tube. Approximately $3 \mu \mathrm{l}$ of internal solution containing cytoplasmic material was then injected into the RNase-free PCR tune using positive pressure. The silver wire located inside the recording pipette was wiped with alcohol wipes in between each neuron to minimize cross sample contamination. After each 5 consecutive aspirations, a pipette was lowered into the tissue without aspiration and processed as above, which was designated as the tissue-stick control.

Extracted cell samples were profiled using the Single Cell-to- $C_{t}$ Kit (Invitrogen). Briefly, cell contents were prepared individually in lysis solution with DNase I. The volume of the mixture Cell Lysis:DNase I solution (9:1) was adjusted to compensate for the added volume of each 

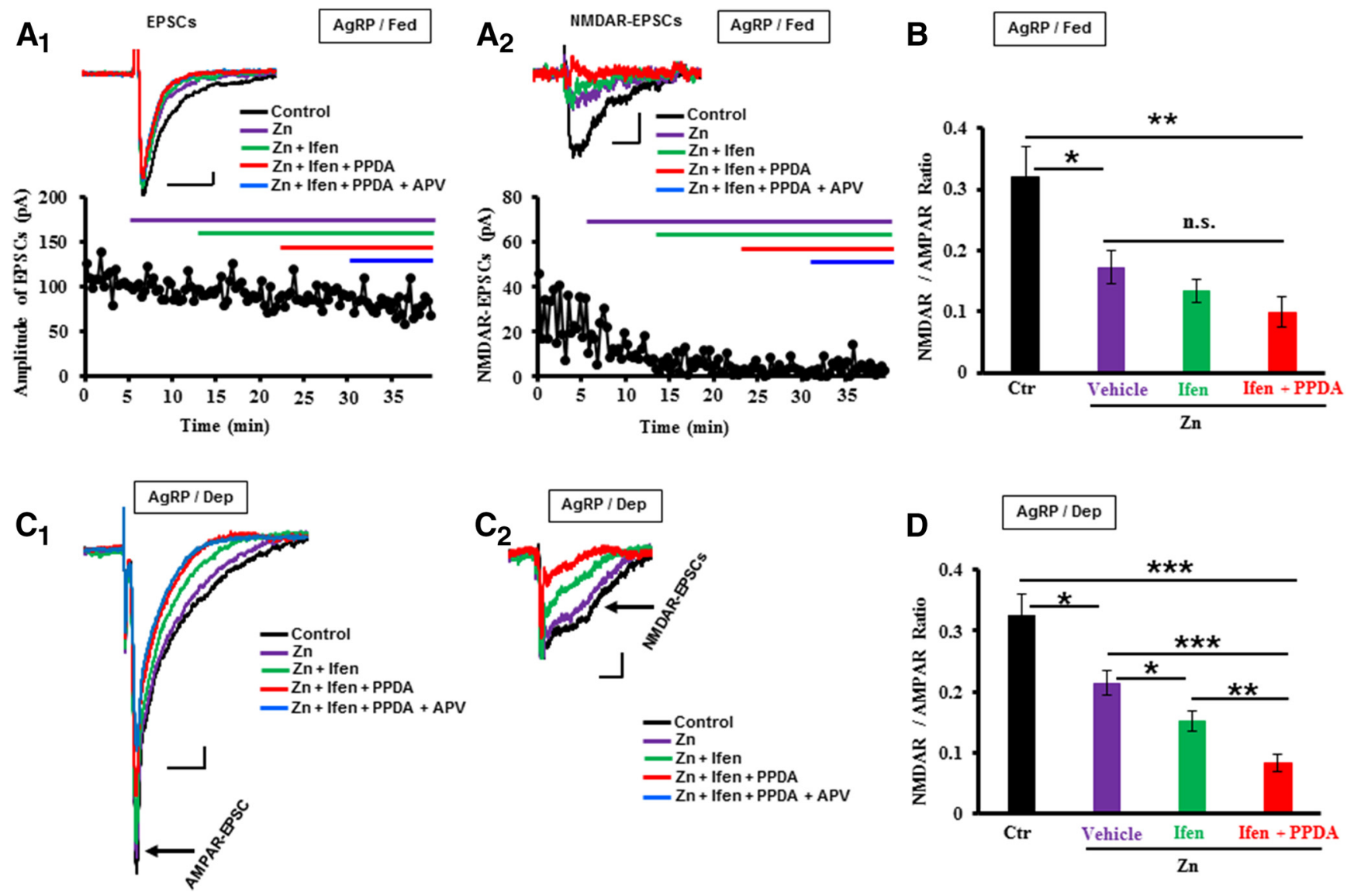

Figure 3. Analysis of NMDAR-mediated EPSCs and NMDAR subpopulations at AgRP neurons in fed and deprived mice. $A_{1}$, Top, A sample of averaged EPSCs $(\sim 15$ trials at the steady state for each condition) recorded at AgRP neurons in fed mice before (control) and during the subsequent treatments with Zn ${ }^{2+}(200 \mathrm{nM})$, Ifen (10 $\left.\mu \mathrm{M}\right)$, PPDA (1.0 $\left.\mu \mathrm{M}\right)$, and APV (50 $\left.\mu \mathrm{M}\right)$. $\boldsymbol{A}_{1}$, Bottom, A representative sample of time-dependent changes of the amplitude of total EPSCs recorded before and during the treatments as indicated by the lines in different colors. $A_{2}$, Top, $A$ sample of NMDAR-EPSCS obtained with subtracting the AMPAR-EPSCs (in APV) from the EPSCs during the control period ( $\sim 15$ trials at the steady state for each condition) as shown in $A_{1}$. $A_{2}$, Bottom, A representative sample of time-dependent changes of the amplitude of NMDAR-EPSCs recorded before and during the treatments as indicated by the colored lines. $A_{1}, A_{2}$, Top traces and the bottom plotting were from the same neuron. $\boldsymbol{B}$, Summary of NMDAR-EPSCs to AMPAR-EPSCs ratio (termed as NMDAR/AMPAR ratio) from the experiments in $\boldsymbol{A}$ (Ctr: $0.32 \pm 0.07 ; \mathrm{Zn}: 0.17 \pm 0.03 ; \mathrm{Zn} / \mathrm{Ifen}$ : $0.13 \pm 0.02 ; \mathrm{Zn} / \mathrm{Ifen} / \mathrm{PPDA}: 0.10 \pm 0.02 ; n=6-14$ slices/3-6 mice). $C_{1}$, A sample of averaged EPSCs $(\sim 15$ trials at the steady state for each condition) recorded at AgRP neurons in deprived mice before (control) and during the subsequent treatments with Zn $(200 \mathrm{nM})$, Ifen $(10 \mu \mathrm{M})$, PPDA $(1.0 \mu \mathrm{M})$, and APV $(50 \mu \mathrm{M}) . C_{2}$, A sample of NMDAR-EPSCs obtained with subtracting the AMPAR-EPSCs (in APV) from the EPSCs during the control period ( $\sim 15$ trials at the steady state for each condition) as shown in $\boldsymbol{C}_{1} \cdot \boldsymbol{C}_{1}, \boldsymbol{C}_{2}$, The traces were from the same neuron. $\boldsymbol{D}$, Summary of NMDAR-EPSCs to AMPAR-EPSCs ratio (termed as NMDAR/AMPAR ratio) from the experiments in C (Ctr: $0.33 \pm 0.03 ; \mathrm{Zn}: 0.21 \pm 0.02 ; \mathrm{Zn} / \mathrm{ffen}: 0.15 \pm 0.02 ; \mathrm{Zn} / \mathrm{Ifen} / \mathrm{PPDA}: 0.08 \pm 0.01 ; n=10-14 \mathrm{slices} / 4-6 \mathrm{mice})$. ${ }^{*} p<0.05$, significant differences between the groups ( $t$ test). ${ }^{* *} p<0.01$, significant differences between the groups $\left(t\right.$ test). ${ }^{* * *} p<0.001$, significant differences between the groups ( $t$ test). Calibration: $\boldsymbol{A}_{1}, \boldsymbol{A}_{2}, \boldsymbol{C}_{1}, \boldsymbol{C}_{2}, 10 \mathrm{pA}, 20 \mathrm{~ms}$. n.s., Not significant. Data are mean \pm SEM.

extracted cell sample. For example, $8 \mu$ l of the mixture was further mixed together with $2 \mu \mathrm{l}$ of each extracted cell sample for $5 \mathrm{~min}$ at room temperature, and $1 \mu \mathrm{l}$ of the stop solution was subsequently added. We kept the total volume of each lysed sample solution as $11 \mu \mathrm{l}$ as required in the Kit for the reverse transcription. We next performed transcription of RNA to cDNA, followed by a multiplexed preamplification of the target genes using TaqMan Gene Expression Assays (Invitrogen). The target genes were NR3A and Rn18s (control). The housekeeping gene Rn18s was not preamplified to avoid reduced amplification of the other genes in the sample due to its high abundance in all cells. qPCR was next performed to obtain the cycle threshold $\left(\mathrm{C}_{\mathrm{t}}\right)$ values of the target gene by using a Bio-Rad CF X384 instrument using recommended amplification parameters for TaqMan-based probes. Three times replications from each sample were performed as well as those from tissue-stick control on the same 384-well plate.

The $C_{t}$, the number of cycles required for the fluorescent signal to cross the threshold (background level as deigned in the Kit), was calculated for each sample. The $C_{t}$ values are opposite proportional to the amount of the target gene in the sample (the lower the $\mathrm{C}_{\mathrm{t}}$ value, the more amount of the target gene in the sample). The cells were not included for analysis if their $\mathrm{qPCR} \mathrm{C}_{\mathrm{t}}$ values were not consistent across the three technical replications or the $\mathrm{C}_{\mathrm{t}}$ values were $<15$ or $>35$. Tissue-stick controls did not display any gene expression. For each sample, we normalized the $C_{t}$ value of the target gene to that of the house-gene Rn18s to minimize the difference caused by the volume of each collected sample. Relative normalized $C_{t}$ values to the samples from fed mice were used to determine the influence of food deprivation on the expression of the target gene NR3A.

Statistical analysis. Data are represented as mean \pm SEM, and error bars indicate SEM. Statistical analyses were performed by use of Prism 6.0 software (GraphPad). $p$ values were calculated by unpaired two-tailed Student's $t$ test.

\section{Results}

Bidirectional regulations of synaptic plasticity at AgRP and POMC neurons by food deprivation

To examine the ability of food deprivation to control activitydependent synaptic plasticity, such as LTP and LTD, whole-cell patch-clamp recordings were made at AgRP and POMC neurons, respectively, in the acute brain slices that include both $\mathrm{VMH}$ and ARC. AgRP and POMC neurons were identified using the tagged 

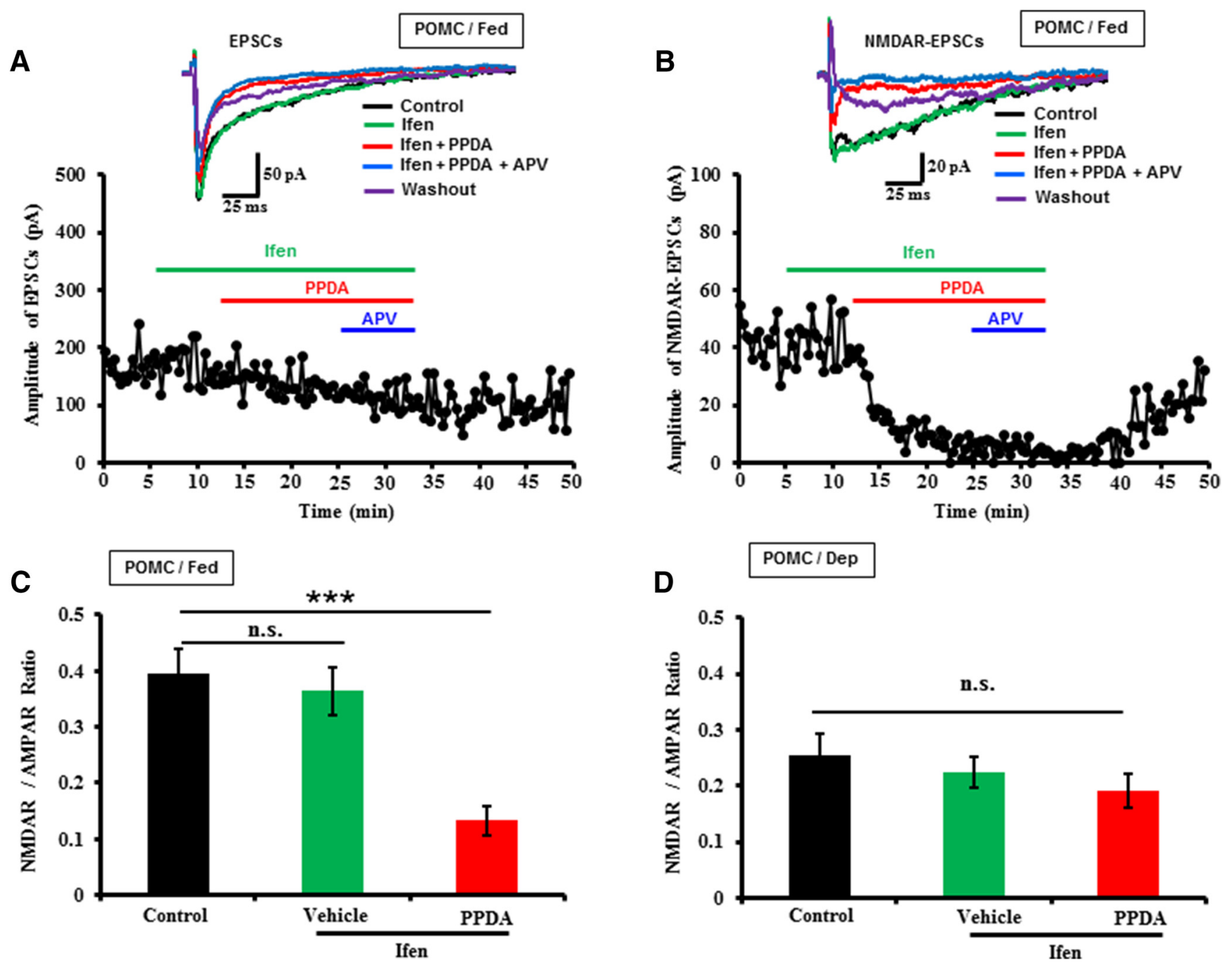

Figure 4. Food deprivation decreased the surface expressions of NR2C/NR2D-containing NMDARs at POMC neurons. $A, B$, Top, Representative averaged AMPAR-EPSCs and NMDAR-EPSCS ( $\sim 15$ trials at the steady state for each condition) recorded at POMC neurons in the fed mice before (control) and during the treatments with Ifen (10 $\mu \mathrm{M})$, PPDA (1.0 $\mu \mathrm{M}), \mathrm{APV}(50 \mu \mathrm{M})$, and washout. Bottom, Representative plotting of time-dependent changes of the amplitude of AMPAR-EPSCs and NMDAR-EPSCs recorded before and during the treatments as indicated by the colored lines. $C$, Summary of NMDAR/AMPAR ratio from the experiments performed at POMC neurons in fed mice (Ctr: $0.39 \pm 0.04$; Ifen: $0.36 \pm 0.04 ;$; Ifen/PPDA: $0.13 \pm 0.03 ; n=12$ slices/5 mice). D, Summary of NMDAR/AMPAR ratio from the experiments performed at POMC neurons in food-deprived mice (Ctr:0.26 $\pm 0.04 ;$ Ifen: $0.22 \pm 0.03 ;$ Ifen/PPDA:0.19 $\pm 0.03 ; n=10$ slices/4 mice). ${ }^{* * *} p<0.001$, significant differences between the groups. n.s., not significant.

GFP under fluorescent microscopy equipped with the electrophysiology recording rig. For instance, AgRP neurons were identified for recordings in the acute brain slices as coexpression of NPY in the neurons of NPY-hrGFP transgenic mice (Hahn et al., 1998). The stimulating electrode was randomly placed at ventromedial, middle, or ventrolateral part of the border between VMH and ARC (Fig. $1 A_{1}-A_{3}$ ).

We observed that one train of tetanic stimulation (100 pulses at $100 \mathrm{~Hz}$ ) of the presynaptic fibers induced robust LTP of excitatory synapse transmissions at AgRP neurons in ad libitum fed mice while the neurons were held at $-60 \mathrm{mV}$ in voltage-clamp mode during induction (Fig. $1 B$ ), whereas the same protocol induced LTD in the mice with $24 \mathrm{~h}$ food deprivation (Fig. 1C). As shown in Figure $1 B$, the amplitude of EPSCs recorded at AgRP neurons in fed mice was significantly increased after induction. By contrast, when the same protocol was applied to the AgRP neurons in deprived mice, the amplitude of EPSCs was significantly decreased after the induction (Fig. 1C). We did not observe apparent difference in the inductions of LTP and LTD with placing the stimulating electrodes at different positions, so we plotted the data together for each group. Interestingly, in an opposite direction, the same induction protocol induced LTD at POMC neurons in fed mice (Fig. 1D), whereas it induced weak LTP in deprived mice (Fig. 1E).

\section{Dependence of the inductions of LTP and LTD on NMDA} receptor subpopulations

Next, we examined whether LTP and LTD inductions at AgRP and POMC neurons depended on NMDA receptors. We find that LTP induction at AgRP neurons in fed mice was dependent on NMDA receptor activation because bath application of NMDAR antagonist APV $(50 \mu \mathrm{M})$ completely abolished LTP induction (Fig. $1 F$ ). Meanwhile, to exclude the possibility that the glucose levels and the induction protocol might influence the hunger states-dependent activity-induced synaptic plasticity, we performed the similar experiments in the glucose level at $5 \mathrm{~mm}$ close to physiological conditions using another induction protocol consisting of 100 pulses at $50 \mathrm{~Hz}$. Under these conditions, we observed that LTP and LTD were still induced at AgRP neurons in fed and deprived mice, respectively (Fig. $2 A, B, H$ ), identical to 

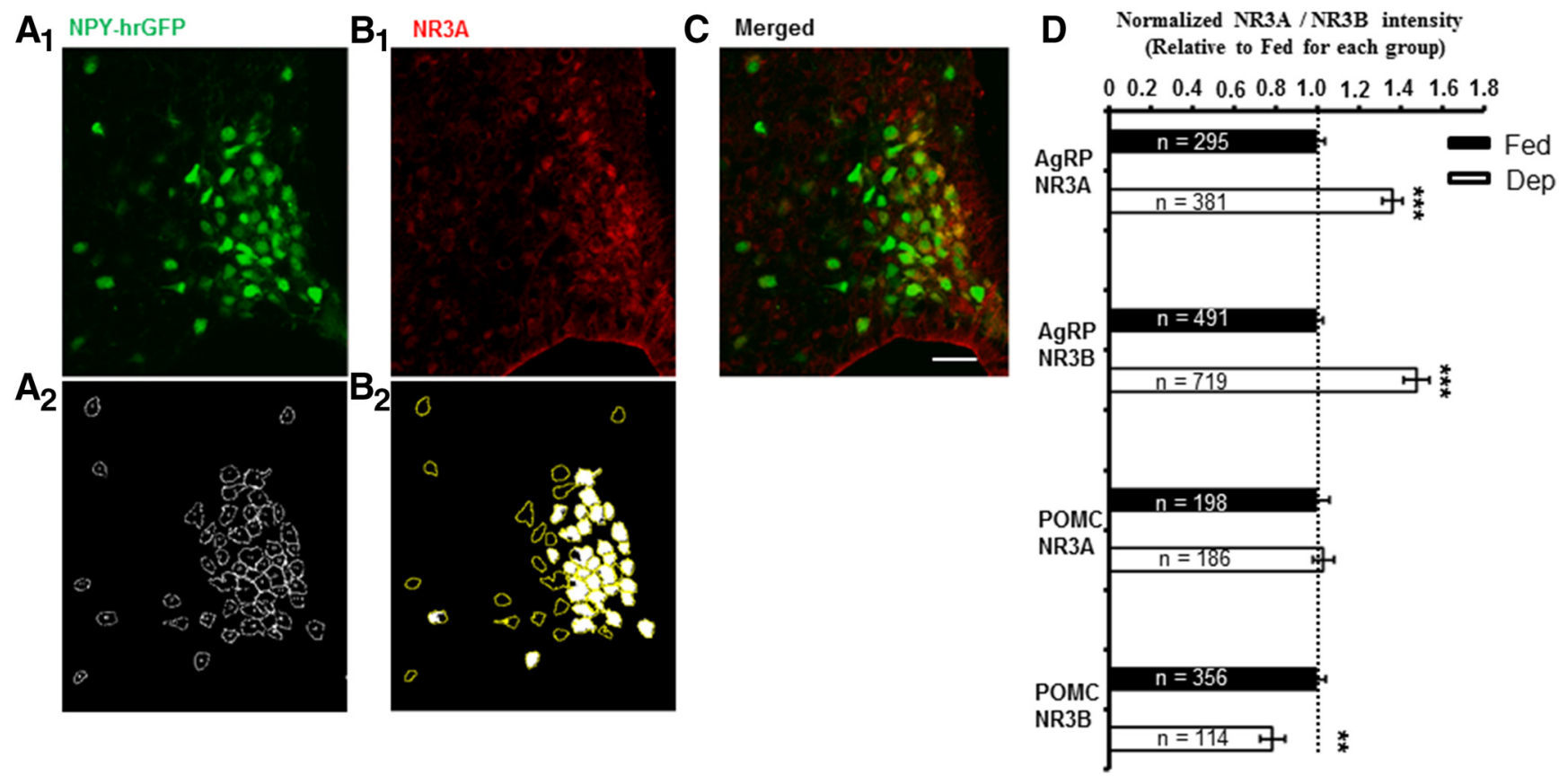

Figure 5. Immunofluorescence assays of NR3A- and NR3B-containing NMDARs at AgRP and POMC neurons in fed and deprived mice. $\boldsymbol{A}_{\boldsymbol{1}}$, Representative confocal image of AgRP neurons expressing hrGFP (green) in brain slice of NPY-hrGFP mice. $\boldsymbol{A}_{2}$, A schematic illustration of the automatically selected AgRP neurons expressing fluorescent protein hrGFP (circles). $\boldsymbol{B}_{\boldsymbol{1}}$, Immunostaining of NR3A with anti-NR3A-conjugated with fluorophore Alexa-555 (red). $\boldsymbol{B}_{2}$, An illustration showing the automatically selected AgRP neurons expressing both hrGFP and NR3A (white). $\boldsymbol{C}$, Image showing the merged AgRP neurons (yellow) expressing both hrGFP and NR3A as presented in $\boldsymbol{A}_{\boldsymbol{1}}$ and $\boldsymbol{B}_{\boldsymbol{1}}$ from the same brain section. $\boldsymbol{D}$, Summary of the results from all experiments, including immunostaining of NR3A and NR3B at AgRP and POMC neurons in fed and deprived mice, respectively. Data were normalized to the averaged signal intensity from fed mice for each group (Fed/AgRP/NR3A: $1.0 \pm 0.03, n=295$ neurons/11 slices/3 mice;Dep/AgRP/NR3A: $1.36 \pm 0.05, n=381$ neurons/9 slices/3 mice; Fed/AgRP/NR3B: $1.0 \pm 0.03, n=491$ neurons $/ 12$ slices/4 mice; Dep/AgRP/NR3B: $1.48 \pm 0.06, n=719$ neurons/11 slices/4 mice; Fed/POMC/NR3A: $1.0 \pm 0.06, n=198$ neurons/13 slices/5 mice; Dep/P0MC/NR3A: $1.03 \pm 0.05, n=186$ neurons $/ 19$ slices/7 mice; Fed/POMC/NR3B: $1 \pm 0.04, n=356$ neurons/17 slices/7 mice; Dep/POMC/NR3B: $0.78 \pm 0.06, n=114$ neurons/12 slices/5 mice). The neurons are those expressing both GFP and NR3A or NR3B for each group. ${ }^{* *} p<0.01$, significant difference from the fed mice for each group ( $t$ test). ${ }^{* * *} p<0.001$, significant difference from the fed mice for each group ( $t$ test).

data presented in Figure 1. Similarly, we observed that LTD and weak LTP were induced at POMC neurons in fed and deprived mice, respectively (Fig. $2 E-G$ ).

Moreover, we observed that the induction of LTP at AgRP neurons in fed mice was blocked in the presence of NR2Aselective blocker $\mathrm{Zn}$ (Fig. $2 \mathrm{C}, \mathrm{H}$ ), whereas the induction of LTD in deprived mice was abolished in the presence of NR2C/D-subunit selective blocker PPDA (Fig. 2D, $H$ ). Also, treatment of the brain slices with PPDA blocked LTD induction at POMC neurons in fed mice (Fig. $2 G, H$ ). Collectively, our results demonstrate that activity-induced synaptic plasticity of the excitatory synapse transmissions in the ARC is under the control of hunger states in a cell type-specific manner probably through NMDA receptor subunits switching.

\section{Bidirectional switch of NMDA receptor subpopulations by hunger states}

We next sought to probe the molecular mechanism underlying hunger states-dependent cell type-specific control of LTP and LTD inductions at AgRP and POMC neurons, respectively. We predict that the surface expressions of NMDAR subpopulations are also under the control of hunger states because it is well demonstrated that one mechanism for bidirectional conversion between LTP and LTD is activation of distinct NMDAR subpopulations (Hrabetova et al., 2000; Paoletti et al., 2013). For instance, NR2A-containing NMDARs contribute to LTP induction, whereas NR2C/D-containing NMDARs contribute to LTD induction (Hrabetova et al., 2000; Paoletti et al., 2013). To test this prediction, we performed pharmacological experiments to identify the NMDAR subunits at AgRP and POMC neurons and examine how hunger states control the NMDAR populations.

Whole-cell voltage-clamp recordings were made at AgRP and POMC neurons while held at $-60 \mathrm{mV}$ in the absence of $\mathrm{Mg}^{2+}$ so that both AMPAR-EPSCs and NMDAR-EPSCs were evoked using the stimulating electrode placed at the dorsal edge of the ARC. Interestingly, we observed long-lasting NMDAR components of the evoked EPSCs at a few of AgRP neurons in fed mice while at more than half of the recorded neurons in the deprived mice, predicting that food deprivation probably induced synaptic incorporations of NR2C/NR2D subpopulations at AgRP neurons. To verify this prediction, we calculated the ratios of NMDAREPSCs and AMPAR-EPSCs as previously reported (Hestrin et al., 1990; Watt et al., 2000; Yang et al., 2003). As expected, we observed that addition of $\mathrm{Zn}(200 \mathrm{nM}$; a NR2A-selective antagonist) (Paoletti et al., 1997, 2013) to the circulating aCSF significantly reduced the amplitude of NMDAR-EPSCs in both fed and fooddeprived mice (Fig. $3 A-D$ ), indicating that the NR2A subunits were expressed at AgRP neurons in both fed and deprived mice. Interestingly, subsequent addition of ifenprodil ( $10 \mu \mathrm{M}$; a selective NR2B antagonist) (Williams, 1993) and PPDA (0.5 $\mu \mathrm{M}$; a NR2C/NR2D-selective blocker) (Hrabetova et al., 2000) induced further significant reductions in NMDAR-EPSCs at AgRP neurons in deprived mice (Fig. $3 C, D$ ) but not in fed mice (Fig. $3 A, B$ ). Together, these results indicate that food deprivation increased synaptic incorporations of NR2C/NR2D subunits at AgRP neurons to counter-regulate NR2A-mediated LTP induction, one of the reasons that food deprivation diminished LTP inductions at AgRP neurons. 
A

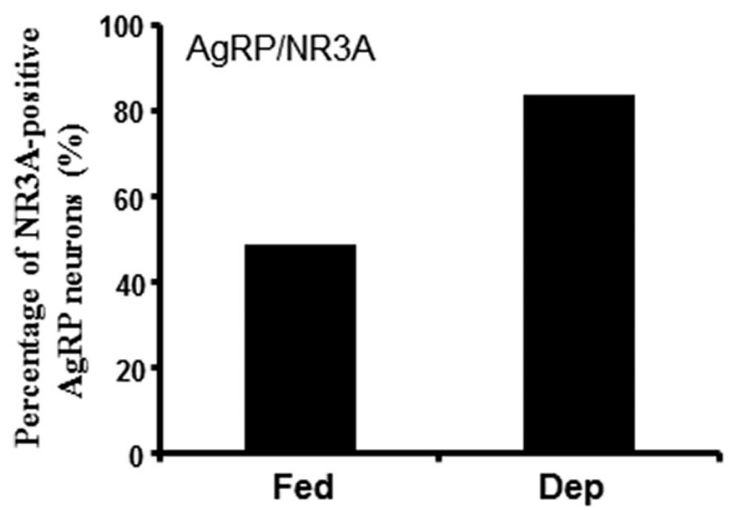

C

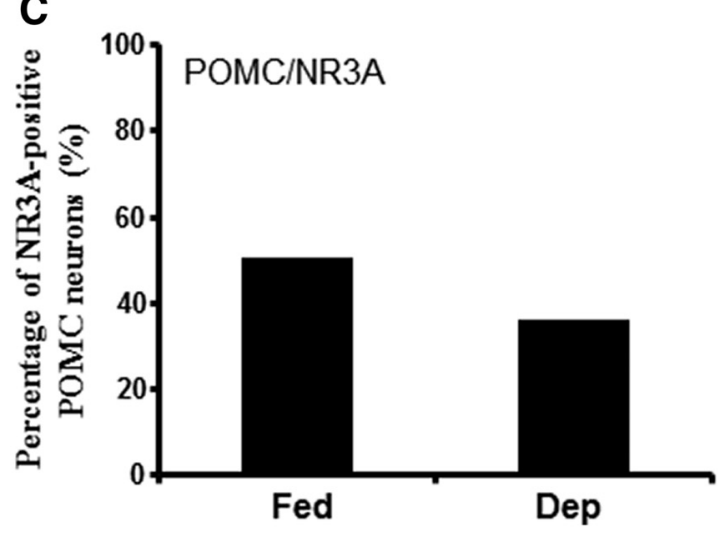

B
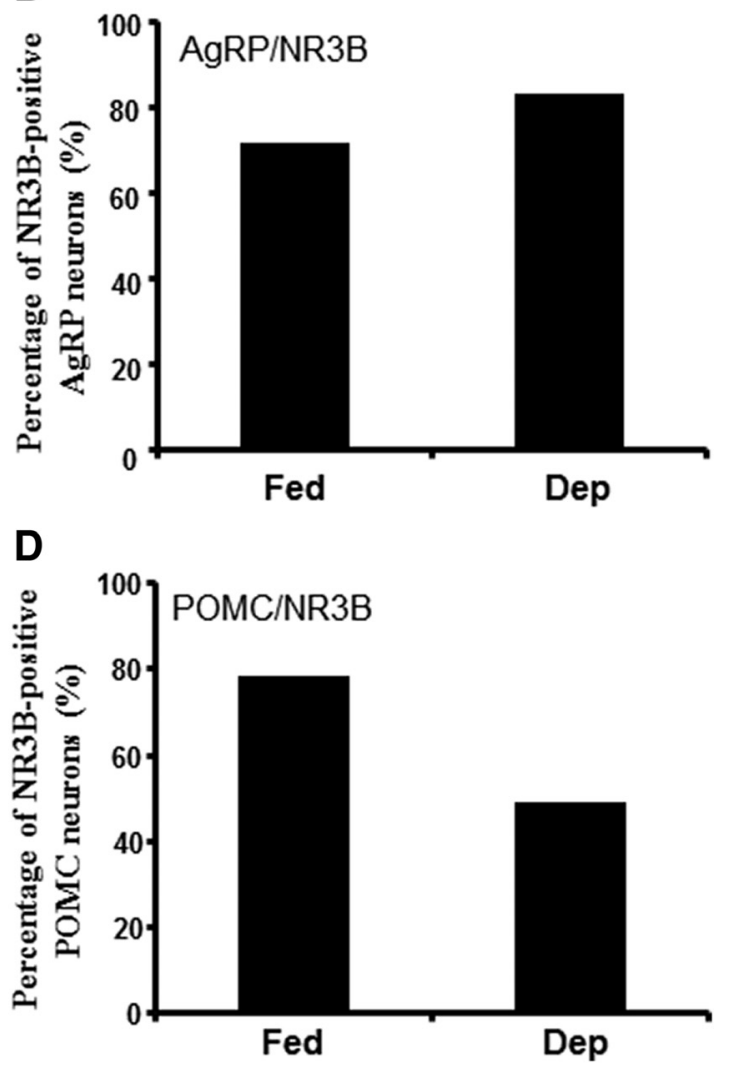

Figure 6. Percentages of the AgRP and POMC neurons expressing both GFP and NR3A or NR3B in fed and deprived mice. $A$, Percentage of AgRP neurons expressing NR3A (Fed: 52.49 from 295 of 562 AgRP-hrGFP neurons; Dep: 84.48 from 381 of 451 AgRP-hrGFP neurons). B, Percentage of AgRP neurons expressing NR3B (Fed: 70.85 from 491 of 693 AgRP-hrGFP neurons; Dep: 83.12 from 719 of 865 AgRP-hrGFP neurons). C, Percentage of POMC neurons expressing NR3A (Fed: 50.51 from 198 of 392 P0MC-EGFP neurons; Dep: 37.73 from 186 of 493 P0MC-EGFP neurons). D, Percentage of POMC neurons expressing NR3B (Fed: 78.41 from 356 of 454 POMC-EGFP neurons; Dep: 47.70 from 114 of 239 P0MC-EGFP neurons).

We next analyzed the NMDAR subpopulations at POMC neurons using the similar approach. No apparent effects of ifenprodil on NMDAR component of EPSCs were observed in both fed and deprived mice (Fig. $4 A-D$ ). Strikingly, subsequent addition of PPDA significantly decreased the NMDAR-EPSCs in fed mice (Fig. 4A-C) but not in deprived mice (Fig. 4D). Meanwhile, we observed that food deprivation decreased the ratios of NMDAR to AMPAR at POMC neurons, compared the control ratios of NMDAR to AMPAR between fed and deprived mice (Fig. 4C,D). Together, these results indicate that food deprivation decreased NR2C/NR2D-containing NMDARs at POMC neurons, one reason that food deprivation converted LTD in fed mice to weak LTP food-deprived mice (Figs. $1 D, E, 2 E-H$ ).

Food deprivation increases NR3 subunits expressions at AgRP neurons, whereas it decreases the expressions at POMC neurons

We next examined whether food deprivation also affected the expressions of NR3-containing receptors because NR3 subunit exerted negative regulatory effects on the growth of dendritic spines (Das et al., 1998) and synaptic functions (Ciabarra et al., 1995; Sucher et al., 1995; Roberts et al., 2009), suggesting the possibility that the changes in NR3 subunit expressions also contributed to the bidirectional control of hunger states on cell typespecific synaptic plasticity. Because of currently lacking NR3 subunit-selective blockers, we performed immunofluorescence assays to determine the changes in the surface expressions of
NR3A and NR3B subunits at the soma of AgRP and POMC neurons in fed and deprived mice, respectively.

We observed that food deprivation significantly increased the fluorescence intensity of surface NR3A and NR3B subunits at AgRP neurons, compared with fed mice (Fig. 5A-D). By contrast, food deprivation decreased the expressions of NR3B subunits at POMC neurons (Fig. 5D). Consistently, food deprivation increased the percentage of the AgRP neurons expressing NR3 subunits to the total AgRP neurons (Fig. 6A,B), whereas it decreased the percentage of POMC neurons expressing NR3 subunits to the total POMC neurons (Fig. 6C,D). Together, these results indicate that the expressions of NR3 subunits at AgRP and POMC neurons are also under the control of hunger states, which at least in part contributes to the hunger states-induced bidirectional regulations on synaptic plasticity.

\section{Bidirectional modulations of D-serine on synapse} transmissions at AgRP and POMC neurons

Next, we further examined the expressions of NR3A and NR3B subunits on AgRP and POMC neurons with performing cell typespecific electrophysiological and pharmacological studies. It is well demonstrated that $\mathrm{D}$-serine, binding to the glycine site on NR1 subunit, facilitates NR1-containing NMDAR-mediated currents (Wolosker et al., 1999; Stevens et al., 2003; Yang et al., 2003; Mothet et al., 2005). Meanwhile, emerging evidence indicated that D-serine reduced NMDA/glycine-evoked currents by the receptors coexpressing NR1/NR2A/NR3A or NR3B (Cia- 

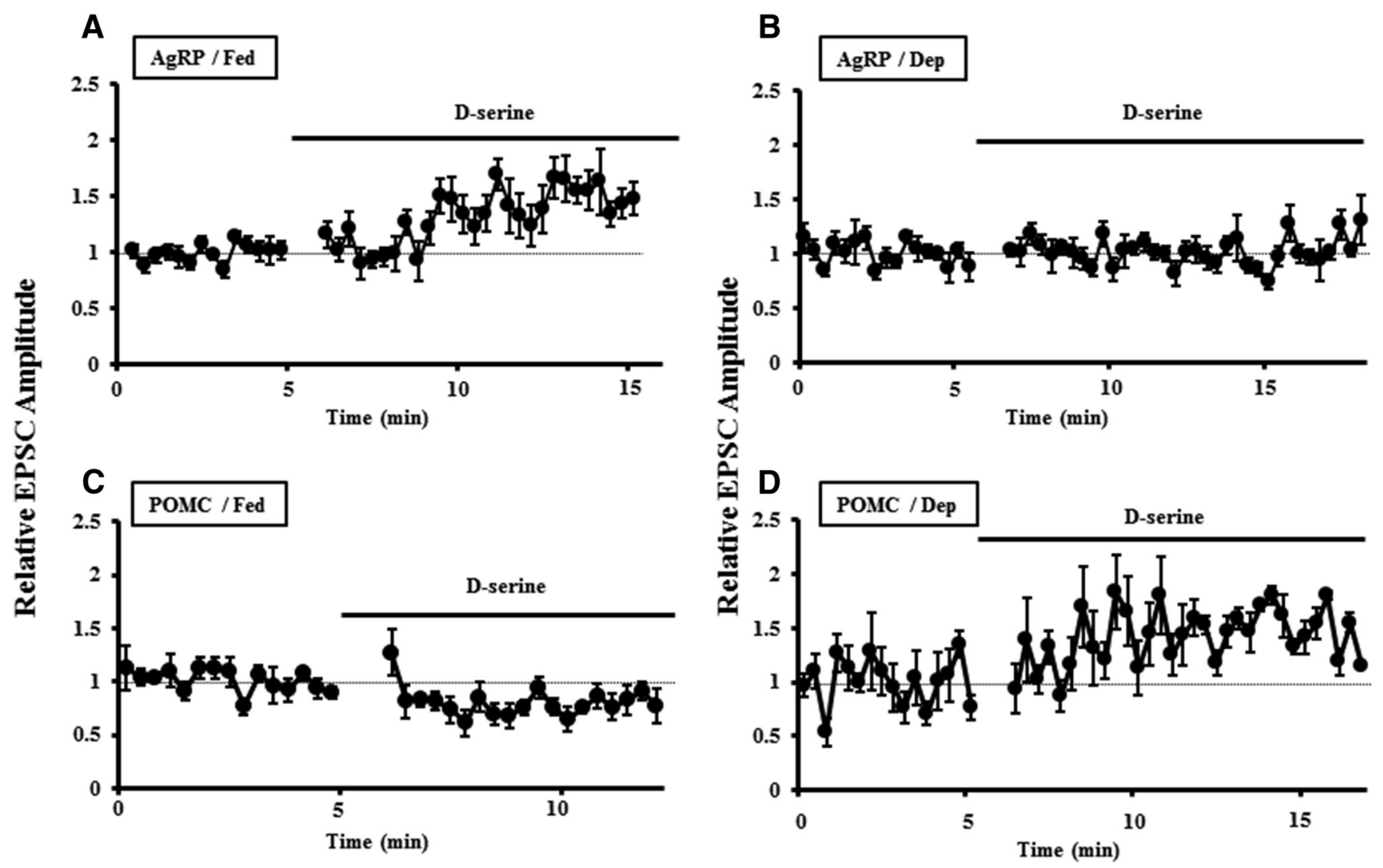

Figure 7. Bidirectional regulations of $\mathrm{D}$-serine on excitatory synapse transmissions at AgRP and POMC neurons in fed and deprived mice. A, Addition of D-serine (100 $\mu \mathrm{M}$ ) to the circulating aCSF increased the amplitude of EPSCS recorded at AgRP neurons in fed mice ( $n=11$ slices $/ 4$ mice), whereas it did not exert apparent effects in food-deprived mice (B; $n=7$ slices $/ 3$ mice). $\boldsymbol{C}, D$-serine significantly decreased the amplitude of EPSCs recorded at POMC neurons in fed mice ( $n=5$ slices $/ 3$ mice). $\boldsymbol{D}$, o-serine increased the amplitude of EPSCs at POMC neurons in food-deprived mice $(n=$ 7 slices/3 mice).

barra et al., 1995; Sucher et al., 1995; Nishi et al., 2001; Chatterton et al., 2002). We thus proposed that D-serine could inhibit the excitatory synapse transmissions at AgRP and POMC neurons expressing NR3 subunits. To test this, we evoked EPSCs at AgRP and POMC neurons, respectively, in fed and deprived mice, and found that addition of D-serine $(100 \mu \mathrm{M})$ in the circulating aCSF facilitated excitatory synapse transmissions at AgRP neuron in fed mice but not deprived mice (Fig. $7 A, B$ ). By contrast, the amplitude of EPSCs recorded at POMC neurons was decreased with the treatment of D-serine in fed mice (Fig. $7 C$ ) but increased in deprived mice (Fig. 7D).

As an independent experiment, we recorded NMDAR-EPSCs in the presence of both zero $\mathrm{Mg}^{2+}$ and DNQX ( $2 \mu \mathrm{M}$; a selective AMPA receptor antagonist) but not CNQX because CNQX blocks glycine binding site on NMDA receptors. As indicated in Figure 8 , we observed that addition of D-serine $(100 \mu \mathrm{M})$ increased the amplitude of NMDAR-EPSCs at AgRP neurons but decreased NMDAR-EPSCs recorded at POMC neurons in fed mice, whereas D-serine decreased NMDAR-EPSCs at AgRP neurons while increased NMDAR-EPSCs at POMC neurons in deprived mice. Moreover, we find that the NMDAR antagonist, APV $(50 \mu \mathrm{M})$, almost completely abolished the NMDARmediated EPSCs recorded at AgRP neurons in fed mice (Fig. $8 C$ ), whereas it exerted less effects on NMDAR-EPSCs in deprived mice (Fig. $8 D$ ), consistent with the insensitivity of NR3 subunits to APV (Chatterton et al., 2002). Together, these results further demonstrate that hunger states also control the expressions of NR3 subunits in a cell type-specific manner.

\section{Discussion}

In this study, we provide, for the first time, evidence that hunger states control the directions of activity-dependent synaptic plasticity, such as LTP, the most extensively studied form of synaptic plasticity that may serve as a cellular mechanism underlying learning and memory (Bliss and Collingridge, 1993; Martin et al., 2000). We report here that, in response to tetanic stimulation of presynaptic afferents and alterations of energy states, the excitatory synaptic strength at AgRP and POMC neurons is distinctly rewired toward opposite directions of potentiation or depression, respectively. Our data suggest that these synaptic dynamics endow the feeding circuits in the ARC with reversible memory properties via previously unknown hunger state-dependent cell typespecific switching of NMDAR subpopulations.

The investigation of both hunger states- and activity-dependent synaptic plasticity would provide new insight into the understandings of the relationship between associative memory and feeding behaviors. To study the ability for hunger states to modulate activity-dependent synaptic plasticity of the appetite control circuits in a physiological condition, we took advantage of the ARC, a key brain region that controls energy intake and expenditure (Williams and Elmquist, 2012).

We find that tetanic stimulation of the presynaptic excitatory afferents induces LTP at orexigenic AgRP neurons in ad libitum fed mice, whereas it induces LTD at the functional distinct anorexigenic POMC neurons (Figs. 1, 2). Interestingly, the LTP 

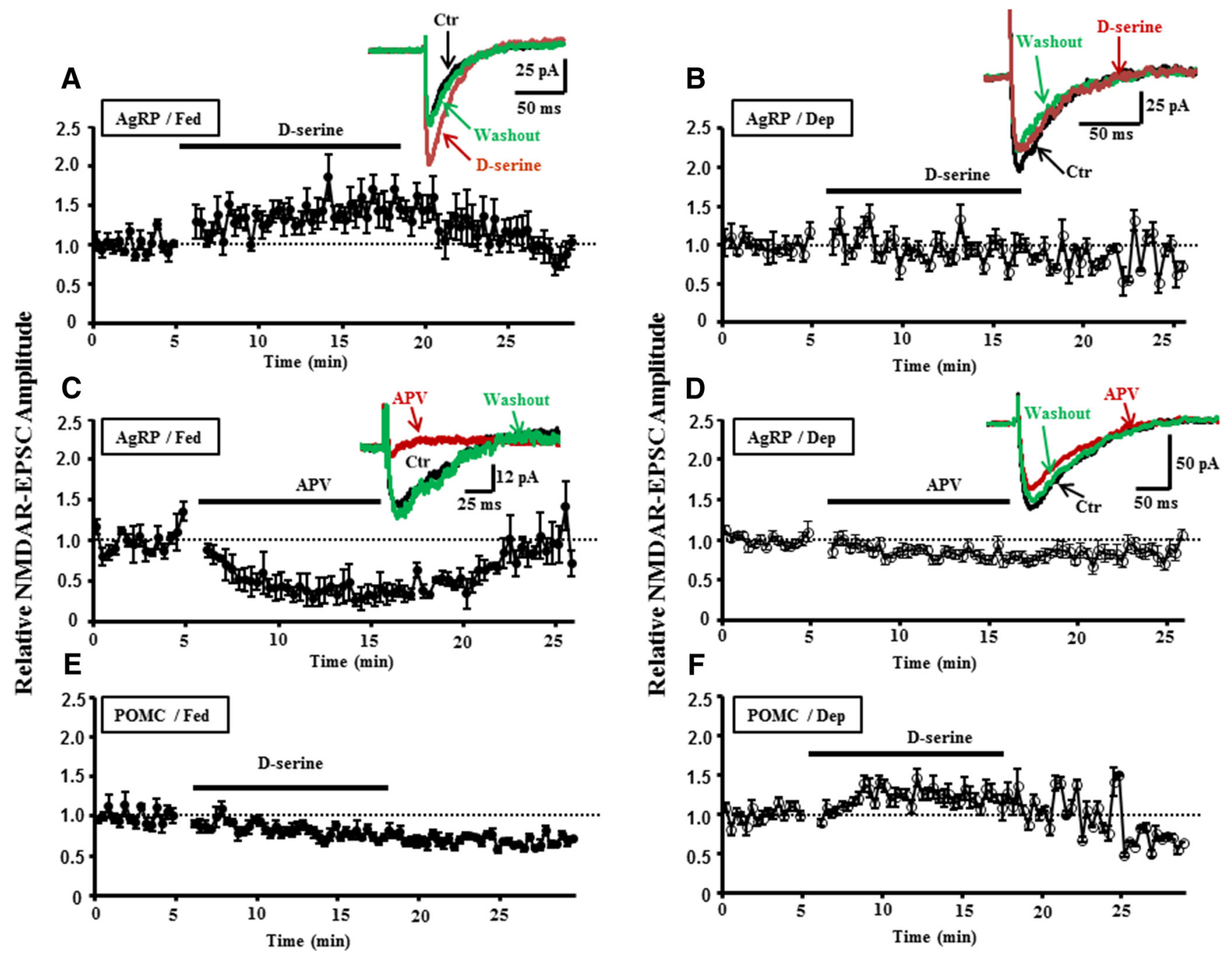

Figure 8. Distinct regulations of D-serine on NMDAR-mediated EPSCS at AgRP and POMC neurons in fed and deprived mice. $A$, D-serine (100 $\mu$ M) increased the amplitude of NMDAR-EPSCS recorded at AgRP neurons in fed mice ( $n=7$ slices/3 mice) but no significant effects in food-deprived mice ( $\boldsymbol{B} ; n=6$ slices $/ 3$ mice). $\boldsymbol{C}$, APV ( $50 \mu \mathrm{m}$ ) prominently reduced NMDAR-EPSCs at AgRP neurons in fed mice ( $n=3$ slices $/ 2$ mice) but only slightly reduced NMDAR-EPSCs at AgRP neurons in deprived mice $(\boldsymbol{D} ; n=8$ slices/4 mice). $\boldsymbol{E}$, D-serine inhibited NMDAR-EPSCs recorded at POMC neurons in fed mice ( $n=6$ slices $/ 3$ mice) but increased NMDAR-EPSCs in deprived mice $(\boldsymbol{F} ; n=6$ slices $/ 3$ mice). Data represent averages from all the experiments for each group. The amplitude of NMDAR-EPSCs was normalized by the mean amplitude observed during the control period before addition of the D-serine or APV. Bars represent the duration of D-serine or APV application. Traces represent samples of averaged EPSCs from one experiment during the control period ( 15 trials $/ 0-5 \mathrm{~min}$ ), test period ( $15 \mathrm{trials} / 10-15 \mathrm{~min}$ ), and washout period ( 15 trials/20 - $25 \mathrm{~min}$ ).

induced at AgRP neurons is converted to LTD with food deprivation, whereas the LTD at POMC neurons in fed mice is converted to weak LTP (Figs. 1,2). Meanwhile, the hunger statesinduced cell type-specific conversions of synaptic plasticity are independent on the glucose levels (Figs. 1, 2). Strikingly, in the experiments of LTP induction, we did not observe significant post-tetanic potentiation (PTP). It is known that significant PTP was usually observed using field recordings and strong tetanic stimulation (Calabresi et al., 1992; Hrabetova and Sacktor, 1997; Hrabetova et al., 2000), whereas no or small PTP was observed using whole-cell recordings and weak tetanus (Bao et al., 1997) or spike timing-dependent protocols (Nishiyama et al., 2000). The significant PTP observed in field recordings probably results from population responses instead of single-cell using whole-cell patch-clamp recording, which we used in this study to meet the requirements of studying cell type-specific plasticity in the ARC. Together, these results at least partially explain why no significant PTP was observed in this study, although we cannot exclude other possibilities. However, small PTP was observed in the experiments of control LTP induction (Fig. 1B) and was reduced in the experiments performed in the presence of NMDAR antagonist APV (Fig. $1 F$ ), consistent with the previous reports (Calabresi et al., 1992; Hrabetova and Sacktor, 1997; Hrabetova et al., 2000). These results suggest that NMDARs at least partially contribute to PTP, although the underlying mechanisms remain unknown. Moreover, emerging evidence indicates that postsynaptic $\mathrm{Ca}^{2+}$ also contributes to PTP (Bao et al., 1997; Reissner et al., 2010). Collectively, the results suggest that PTP is probably determined by stimuli intensity, of both presynaptic and postsynaptic aspects, and can be diminished by NMDA receptor antagonists to some extent. Further studies are needed to investigate the mechanism(s) underlying PTP.

To probe the molecular mechanism underlying hunger statesdependent conversions of synaptic plasticity, we examined NMDAR subpopulations at AgRP and POMC neurons in our experimental conditions because the NMDAR subpopulations control the directions of NMDAR-dependent synaptic plasticity (Hrabetova et al., 2000). We find that the inductions of LTP and LTD at AgRP neurons are NMDAR-dependent because the LTP induction in fed mice is blocked by NMDAR antagonist APV and 


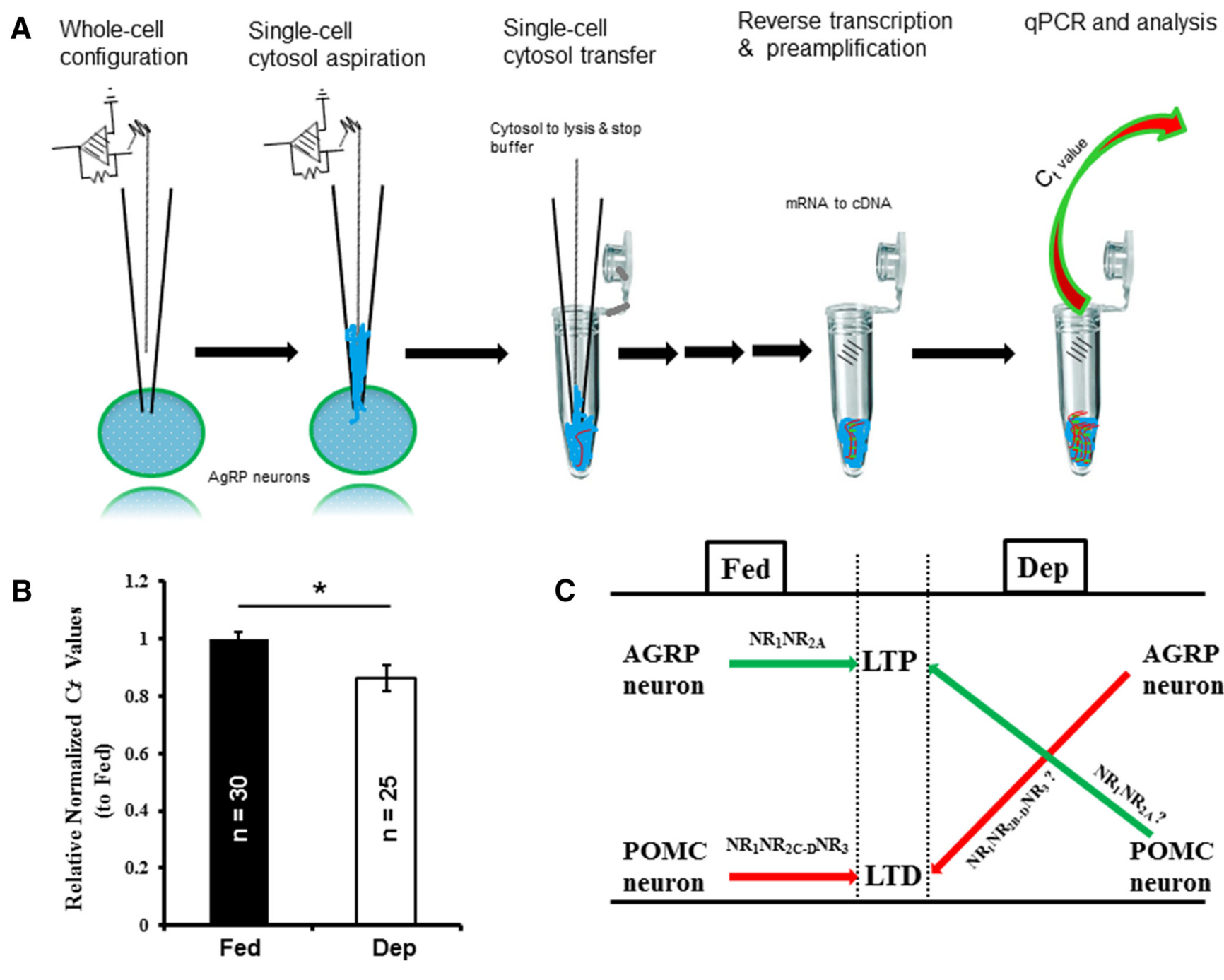

Figure 9. Food deprivation significantly increased NR3A gene expressions at AgRP neurons. A, A schematic illustration for single-cell gene expression profiling and assays. Briefly, whole-cell configurations were first made, and cytosol for each cell was aspirated and profiled individually for quantitative assays of the target gene. $\boldsymbol{B}$, Summary of the results from the experiments as illustrated from in $\boldsymbol{A}$. Food deprivation significantly reduced the $C_{\mathrm{t}}$ values for the NR3A gene. For each cell, we normalized the $C_{\mathrm{t}}$ value of the NR3A gene to that of the house-gene $R n 18$ s. Relative normalized $C_{\mathrm{t}}$ values to the averaged $C_{\mathrm{t}}$ value from fed mice were used to determine the influence of food deprivation on the expression of the NR3A genes (Fed: $1 \pm 0.02, n=30$ neurons $/ 3$ mice; Dep: $0.86 \pm 0.04, n=25$ neurons/3 mice). C, A proposed model that hunger states control the directions of activity-dependent synaptic plasticity at AgRP and POMC neurons by switching the NMDAR subpopulations. For instance, AgRP neurons in fed mice prominently express $\mathrm{NR}_{2 \mathrm{~A}}$-containing NMDARs, which contribute to LTP induction, whereas food deprivation promotes synaptic incorporation of $\mathrm{NR}_{2 \mathrm{~B}-\mathrm{D}} / \mathrm{NR}_{3}$ subunits, which contribute to LTD induction. By contrast, food deprivation might facilitate LTP induction at POMC neurons by reducing $\mathrm{NR}_{2 C} / \mathrm{NR}_{2 D} / \mathrm{NR}_{3}$ subunits while increasing $\mathrm{NR}_{2 \mathrm{~A}}$ subunit. ${ }^{*} p<0.05$ ( $t$ test).

NR2A-selective blocker Zn (Figs. 2C,H), whereas the LTD induction in deprived mice is blocked by $\mathrm{NR}_{2 \mathrm{C}} / \mathrm{NR}_{2 \mathrm{D}}$ subunit-selective blocker PPDA (Fig. 2D,H). Together, our results suggest that hunger states control the directions of activity-dependent synaptic plasticity probably by switching surface NMDAR subunits.

We combine cell type-specific electrophysiological, pharmacological, and single-cell gene profiling techniques to determine the NMDAR subunits at AgRP and POMC neurons in fed and deprived animals, respectively. Based on these experiments, we propose a model that food deprivation increases the surface expressions of NMDAR subunits at the orexigenic AgRP neurons that contribute to LTD induction, such as $\mathrm{NR}_{2 \mathrm{C}} / \mathrm{NR}_{2 \mathrm{D}} / \mathrm{NR}_{3}$, whereas it decreases them at the anorexigenic POMC neurons. Because of lacking NR3-selective blockers, we took advantage of the distinct regulations of D-serine on NR1/NR2- and NR3containing receptors to identify NR3 subunits (Ciabarra et al., 1995; Sucher et al., 1995; Wolosker et al., 1999; Nishi et al., 2001; Chatterton et al., 2002; Stevens et al., 2003; Yang et al., 2003;
Mothet et al., 2005). Consistently, we find that D-serine increases the amplitudes of EPSCs recorded at AgRP neurons but decreased at POMC neurons in fed mice, whereas it exerts opposite effects in the deprived mice (Figs. 7, 8). To validate the hunger states-induced NMDAR subpopulation switch, we performed single-cell gene analysis. For instance, we find that food deprivation significantly increased the expressions of the genes encoding NR3A subunits, as is evidenced by that food deprivation decreases the $C_{t}$ of the target gene of NR3A to cross the fluorescence threshold (baseline) (Fig. 9A,B), opposite proportional to the amount of the target gene in the sample.

Collectively, our data demonstrate that energy states bidirectionally control synaptic plasticity of feeding circuits by regulating NMDAR subpopulations in a cell type-specific manner. We thus propose a reversible memory configuration constructed from energy states-dependent cell type-specific bidirectional conversions of activity-induced synaptic plasticity (Fig. 9C). Meanwhile, there is increasing evidence demonstrating distinct 
functional roles played by NMDAR signaling in the control of food intake and energy states (Burns and Ritter, 1997; Hung et al., 2006; Stanley et al., 2011; Liu et al., 2012). Together, these findings reveal a new reciprocal interaction between energy states and associative memory, one that might serve as a target for therapeutic treatments of the energy-related memory disorders or vice versa. Further studies on the molecular mechanism underlying energy states-induced switch of NMDAR subunits are needed, and the use of cell type-specific NMDAR subunits manipulation techniques may be useful toward controlling eating disorders resulting from impaired associative memory or vice versa.

\section{References}

Aponte Y, Atasoy D, Sternson SM (2011) AGRP neurons are sufficient to orchestrate feeding behavior rapidly and without training. Nat Neurosci 14:351-355. CrossRef Medline

Atasoy D, Betley JN, Su HH, Sternson SM (2012) Deconstruction of a neural circuit for hunger. Nature 488:172-177. CrossRef Medline

Awobuluyi M, Yang J, Ye Y, Chatterton JE, Godzik A, Lipton SA, Zhang D (2007) Subunit-specific roles of glycine-binding domains in activation of NR1/NR3 N-methyl-D-aspartate receptors. Mol Pharmacol 71:112-122. CrossRef Medline

Bao JX, Kandel ER, Hawkins RD (1997) Involvement of pre and postsynaptic mechanisms in posttetanic potentiation at Aplysia synapses. Science 275:969-973. CrossRef Medline

Bliss TV, Collingridge GL (1993) A synaptic model of memory: long-term potentiation in the hippocampus. Nature 361:31-39. CrossRef Medline

Burns GA, Ritter RC (1997) The non-competitive NMDA antagonist MK801 increases food intake in rats. Pharmacol Biochem Behav 56:145-149. CrossRef Medline

Calabresi P, Pisani A, Mercuri NB, Bernardi G (1992) Long-term potentiation in the striatum in unmasked by removing the voltage-dependent magnesium block of NMDA receptor channels. EurJ Neurosci 4:929-935. CrossRef Medline

Chatterton JE, Awobuluyi M, Premkumar LS, Takahashi H, Talantova M, Shin Y, Cui J, Tu S, Sevarino KA, Nakanishi N, Tong G, Lipton SA, Zhang D (2002) Excitatory glycine receptors containing the NR3 family of NMDA receptor subunits. Nature 415:793-798. CrossRef Medline

Ciabarra AM, Sullivan JM, Gahn LG, Pecht G, Heinemann S, Sevarino KA (1995) Cloning and characterization of chi-1: a developmentally regulated member of a novel class of the ionotropic glutamate receptor family. J Neurosci 15:6498-6508. Medline

Das S, Sasaki YF, Rothe T, Premkumar LS, Takasu M, Crandall JE, Dikkes P, Conner DA, Rayudu PV, Cheung W, Chen HS, Lipton SA, Nakanishi N (1998) Increased NMDA current and spine density in mice lacking the NMDA receptor the NMDA receptor subunit NR3A. Nature 393:377381. CrossRef Medline

Dingledine R, Borges K, Bowie D, Traynelis SF (1999) The glutamate receptor ion channels. Pharmacol Rev 51:7-61. Medline

Gordon GR, Bains JS (2006) Can homeostatic circuits learn and remember? J Physiol 576:341-347. CrossRef Medline

Hahn TM, Breininger JF, Baskin DG, Schwartz MW (1998) Coexpression of Agrp and NPY in fasting-activated hypothalamic neurons. Nat Neurosci 1:271-272. CrossRef Medline

Hestrin S, Sah P, Nicoll RA (1990) Mechanisms generating the time course of dual component excitatory synaptic currents recorded in hippocampal slices. Neuron 5:247-253. CrossRef Medline

Hrabetova S, Serrano P, Blace N, Tse HW, Skifter DA, Jane DE, Monaghan DT, Sacktor TC (2000) Distinct NMDA receptor subpopulations contribute to long-term potentiation and long-term depression induction. J Neurosci 20:RC81. Medline

Hrabetova S, Sacktor TC (1997) Long-term potentiation and long-term depression are induced through pharmacologically distinct NMDA receptors. Neurosci Lett 226:107-110. CrossRef Medline

Hung CY, Covasa M, Ritter RC, Burns GA (2006) Hindbrain administration of NMDA receptor antagonist AP-5 increases food intake in the rat. Am J Physiol Regul Integr Comp Physiol 290:R642-R651. CrossRef Medline

Jennings JH, Rizzi G, Stamatakis AM, Ung RL, Stuber GD (2013) The inhibitory circuit architecture of the lateral hypothalamus orchestrates feeding. Science 341:1517-1521. CrossRef Medline

Liu T, Kong D, Shah BP, Ye C, Koda S, Saunders A, Ding JB, Yang Z, Sabatini
BL, Lowell BB (2012) Fasting activation of AgRP neurons requires NMDA receptors and involves spinogenesis and increased excitatory tone. Neuron 73:511-522. CrossRef Medline

Martin SJ, Grimwood PD, Morris RG (2000) Synaptic plasticity and memory: an evaluation of the hypothesis. Annu Rev Neurosci 23:649-711. CrossRef Medline

Matsuda K, Fletcher M, Kamiya Y, Yuzaki M (2003) Specific assembly with the NMDA receptor 3B subunit controls surface expression and calcium permeability of NMDA receptors. J Neurosci 23:10064-10073. Medline

Mothet JP, Pollegioni L, Ouanounou G, Martineau M, Fossier P, Baux G (2005) Glutamate receptors activation triggers a calcium- and SNARE protein-dependent release of the gliotransmitter D-serine. Proc Natl Acad Sci U S A 102:5606-5611. CrossRef Medline

Nishiyama M, Hong K, Mikoshiba K, Poo MM, Kato K (2000) Calcium stores regulate the polarity and input specificity of synaptic modifications. Nature 408:584-588. CrossRef Medline

Nishi M, Hinds H, Lu HP, Kawata M, Hayashi Y (2001) Motoneuron-specific expression of NR3B, a novel NMDA-type glutamate receptor subunit that works in a dominant-negative manner. J Neurosci 21:RC185. Medline

Paoletti P, Ascher P, Neyton J (1997) High-affinity zinc inhibition of NMDA NR1-NR2A receptors. J Neurosci 17:5711-5725. Medline

Paoletti P, Bellone C, Zhou Q (2013) NMDA receptor subunit diversity: impact on receptor properties, synaptic plasticity and disease. Nat Rev Neurosci 14:383-400. CrossRef Medline

Reissner KJ, Pu L, Schaffhausen JH, Boyle HD, Smith IF, Parker I, Carew T] (2010) A novel postsynaptic mechanism for heterosynaptic sharing of short-term plasticity. J Neurosci 30:8797-8806. CrossRef Medline

Roberts AC, Díez-García J, Rodriguiz RM, López IP, Luján R, MartínezTurrillas R, Picó E, Henson MA, Bernardo DR, Jarrett TM, Clendeninn DJ, López-Mascaraque L, Feng G, Lo DC, Wesseling JF, Wetsel WC, Philpot BD, Pérez-Otaño I (2009) Downregulation of NR3A-containing NMDARs is required for synapse maturation and memory consolidation. Neuron 63:342-356. CrossRef Medline

Schneeberger M, Dietrich MO, Sebastián D, Imbernón M, Castaño C, Garcia A, Esteban Y, Gonzalez-Franquesa A, Rodríguez IC, Bortolozzi A, GarciaRoves PM, Gomis R, Nogueiras R, Horvath TL, Zorzano A, Claret M (2013) Mitofusin 2 in POMC neurons connects ER stress with leptin resistance and energy imbalance. Cell 155:172-187. CrossRef Medline

Stanley BG, Urstadt KR, Charles JR, Kee T (2011) Glutamate and GABA in lateral hypothalamic mechanisms controlling food intake. Physiol Behav 104:40-46. CrossRef Medline

Stevens ER, Esguerra M, Kim PM, Newman EA, Snyder SH, Zahs KR, Miller RF (2003) D-serine and serine racemase are present in the vertebrate retina and contribute to the physiological activation of NMDA receptors. Proc Natl Acad Sci U S A 100:6789-6794. CrossRef Medline

Sucher NJ, Akbarian S, Chi CL, Leclerc CL, Awobuluyi M, Deitcher DL, Wu MK, Yuan JP, Jones EG, Lipton SA (1995) Developmental and regional expression pattern of a novel NMDA receptor-like subunit (NMDAR-L) in the rodent brain. J Neurosci 15:6509-6520. Medline

Watt AJ, van Rossum MC, MacLeod KM, Nelson SB, Turrigiano GG (2000) Activity coregulates quantal AMPA and NMDA currents at neocortical synapses. Neuron 26:659-670. CrossRef Medline

Williams K (1993) Ifenprodil discriminates subtypes of the N-methyl-Daspartate receptor: selectivity and mechanisms at recombinant heteromeric receptors. Mol Pharmacol 44:851-859. Medline

Williams KW, Elmquist JK (2012) From neuroanatomy to behavior: central integration of peripheral signals regulating feeding behavior. Nat Neurosci 15:1350-1355. CrossRef Medline

Wolosker H, Blackshaw S, Snyder SH (1999) Serine racemase: a glial enzyme synthesized D-serine to regulate glutamate- $\mathrm{N}$-methyl-Daspartate neurotransmission. Proc Natl Acad Sci U S A 96:1340913414. CrossRef Medline

Yang L, Qi Y, Yang Y (2015) Astrocytes control food intake by inhibiting AGRP neuron activity via adenosine A1 receptors. Cell Rep 11:798-807. CrossRef Medline

Yang Y, Ge W, Chen Y, Zhang Z, Shen W, Wu C, Poo M, Duan S (2003) Contribution of astrocytes to hippocampal long-term potentiation through release of D-serine. Proc Natl Acad Sci U S A 100:15194-15199. CrossRef Medline

Yang Y, Atasoy D, Su HH, Sternson SM (2011) Hunger states switch a flipflop memory circuit via a synaptic AMPK-dependent positive feedback loop. Cell 146:992-1003. CrossRef Medline 